(C) The Author(s), 2022. Published by Cambridge University Press on behalf of the Arizona Board of Regents on behalf of the University of Arizona. This is an Open Access article, distributed under the terms of the Creative Commons Attribution licence (https://creativecommons.org/licenses/by/4.0/), which permits unrestricted re-use, distribution, and reproduction in any medium, provided the original work is properly cited.

\title{
COMPARING ANALYSIS OF PRETREATMENT METHODS OF WOOD AND BONE MATERIALS FOR THE CHRONOLOGY OF PERIPHERAL BURIALS AT TUNNUG 1, TUVA REPUBLIC, RUSSIA - ERRATUM
}

Fatima Pawełczyk • Irka Hajdas • Timur Sadykov • Jegor Blochin • Gino Caspari

https://doi.org/10.1017/RDC.2021.100, published by Cambridge University Press, 1 December 2021.

In the original publication of this article (Pawełczyk et al. 2021), the order of the authors was listed incorrectly. The correct author list appears above.

The original article has been updated. The editors and publisher apologize for this error.

\section{REFERENCE}

Pawełczyk F, Hajdas I, Sadykov T, Blochin J, Caspari G. 2021. Comparing analysis of pretreatment methods of wood and bone

materials for the chronology of peripheral burials at Tunnug 1, Tuva Republic, Russia. Radiocarbon. doi: 10.1017/RDC.2021.100. 